
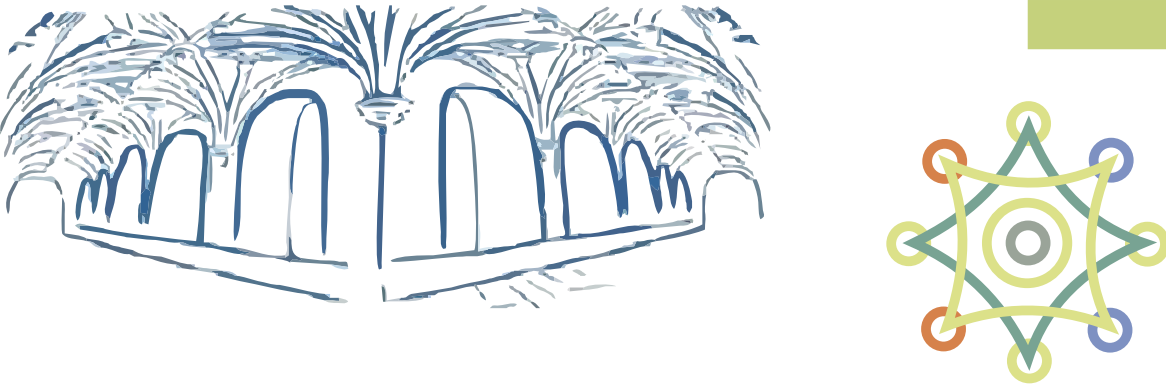

Anabela, Guedes, / Isabel, Oliveira /Paula, Santos/Sandra, Antunes Habilidades comunicativas de lenguas extranjeras en estudios de secretariado-Foreign languages communicative skills in Secretarial Studies Revista Practicum, 5(2), 83-96 DOI 10.24310/RevPracticumrep.v5i2.10159
R E V I S T A PRACTICUM

Número 5(2), Julio-Diciembre, 2020 ISSN: 2530-4550

\title{
Foreign languages communicative skills in Secretarial Studies
}

\section{Habilidades comunicativas de lenguas extranjeras en estudios de secretariado}

\author{
Anabela Guedes \\ IPV-ESTGL \\ aguedes@estgl.ipv.pt \\ Isabel Oliveira \\ IPV-ESTGL \\ ioliveira@estgl.ipv.pt \\ Paula Santos \\ IPV-ESTGL \\ psantos@estgl.ipv.pt \\ Sandra Antunes \\ IPV-ESTGL \\ santunes@estgl.ipv.pt
}

\section{Resumen}

El objetivo de la enseñanza de idiomas extranjeros es permitir que los estudiantes desarrollen y utilicen aún más las habilidades del idioma inglés en contextos generales y específicos, y este objetivo siempre se logra a través de la práctica de las cuatro habilidades: lectura, escritura, comprensión auditiva y expresión oral. En lo que respecta a las habilidades para hablar, los profesores de inglés suelen utilizar la evaluación oral y las situaciones de juego de roles para evaluar las habilidades de los estudiantes. Los estudiantes que desean obtener un título en 
Estudios Secretariales y Asistencia Administrativa en ESTGL y desean convertirse en profesionales administrativos exitosos deben ser conscientes de la importancia del inglés en sus futuros trabajos y deben estar preparados para comunicarse en contextos reales. Este trabajo, utilizando una metodología descriptiva humanista-interpretativa, tiene como objetivos reconocer que el enfoque del juego de roles es una de las técnicas más que un profesor de idiomas puede explorar y corroborar el enfoque de la enseñanza del lenguaje comunicativo utilizado en la Licenciatura en Estudios Secretariales y Asistencia Administrativa. Llegamos a la conclusión de que aumenta la confianza de los estudiantes y las habilidades de interacción personal.

\section{Abstract}

The aim of the foreign languages teaching is to enable students to further develop and use English language skills in general and specific contexts and this aim is always achieved through the practice of the four skills - reading, writing, listening and speaking. As far as speaking skills are concerned, oral assessment and role-play situations are often used by English teachers to assess students' skills. Students pursuing a degree in Secretarial Studies and Administrative Assistance at ESTGL and want to become successful administrative professionals must be aware of the importance of English in their future jobs and must be prepared to communicate in real contexts. This paper, using a descriptive humanistic-interpretative methodology, aims to acknowledge that role-play is one technique a language teacher can explore and to substantiate the Communicative Language Teaching approach used in the Bachelor of Secretarial Studies and Administrative Assistance. We concluded that it boosts students' confidence and their personal interaction skills.

\section{Palabras claves}

Juego de roles, Interacción, Aprendizaje de L2, Enseñanza de lenguaje comunicativo, Habilidades de habla

\section{Keywords}

Role-play, Interaction, L2 learning, Communicative Language Teaching, Speaking skills.

\section{Introducción}

The term role-play refers to the changing of someone's behaviour to assume a role. The Oxford English dictionary defines role playing as the acting out of a 
particular role, either consciously (as a technique in psychotherapy or training) or unconsciously (in accordance with the perceived expectations of society).

Jacob Moreno, who was a doctor, first used this technique in the 1920s with his patients. As a psychiatrist, he realised that his patients gained more by exploring their problems by acting them than by talking about them. By the late 1940s role playing became a recognized part of business community and in the 1970s it was widely used as part of behaviour therapy for assertion training and social skills training. As far as education is concerned, it has been known as a method in education since the late 1940s (Siddiqui,2008).

This type of activity brings vitality to the teaching-learning process and it is an excellent methodology to help students become interested and involved, as they integrate knowledge into action, addressing problems, exploring alternatives, and looking for creative solutions. Besides, role-play intensifies and accelerates learning and it is the best way to develop the skills such as initiative, communication, problem-solving, self-awareness, and to work cooperatively as well as to prepare students to real life situations (Chesler, M. A., \& Fox, R. S., 1966).

One aspect of role playing was that of diagnosis or assessment, which means that this technique enables to test of how a person would act when placed in an imagined or pretend problematic situation. The conclusion is that the effective use of role-plays can add variety to the kinds of activities students are asked to perform. It also encourages thinking and creativity, lets students develop and practice new language and behavioural skills in a relatively safe setting, and can create the motivation and involvement necessary for real learning to occur (Guedes, 2009).

One of the primary concerns while teaching a foreign language like English is to help students understand the importance of communication in real contexts. The role-play approach is one of the most powerful techniques a language teacher can explore as it enhances students' learning and prepares them to deal with all kind of speakers. Good students can help not so good students to communicate using the vocabulary they know, rephrasing complex sentences and achieve the same goal: communication. (Guedes, 2009)

\section{Methodology}

This work follows a descriptive humanistic-interpretative methodology, considering its objectives. This methodology is particularly the one that underlies exploratory-descriptive studies, combining the collection of secondary data.

This investigation intended, by reading scientific articles and analysing the results of other investigations on the theme, to get to know the state of the art and to come up with some proposals that answer the questions that motivate us. 
The work was based on a bibliographic exploration rather oriented to the data collection in papers and scientific studies carried out around the concepts of roleplay and communicative language teaching, submitted to content analysis procedures (qualitative, direct and exploitative) and of argumentative analysis as well.

\section{Contexts of 12 learning}

The title given to this part of the reflection compels us, immediately, to start by defining what a theory is. In a simple way, we can say that a theory provides a general explanation for observations made over time, it explains and predicts behaviour and can never be established beyond all doubt. It is also prudent to refer that a theory can be adapted and finally we must not forget that theories hardly ever have to be thrown out completely if carefully tested but sometimes a theory may be widely accepted for a long time and later disproved.

There has been much increase in the past years in research accompanied by wider views of language, regard as its dynamic nature, and awareness to many contexts of L2 learning (Kaplan, 2002). Various theoretical perspectives (articulated in a set of interrelated hypotheses about L2 acquisition) suggested by Krashen (1982) are considered the most influential in the field by, for example, Hadley (1993) and Swaffar and Bacon (1993).

Even though proficiency in L2 is now understood not only as awareness of its linguistic system, but also as the capacity to communicate successfully in the target language (Ellis, 1997; Mitchell \& Myles, 1998), the role of formal linguistics in the explanation of $\mathrm{L} 2$ competence is supported by some researchers such as Juffs (2002) and White et al.(1997).

Cognitive models present learning as a lively process in which learners intentionally choose and systematize information, relate it to what they already know, keep the information they consider to be important, use the information in suitable contexts, and reflect on their own success in learning (Harrington, 2002; Schmidt, 1990). At the same time, L2 acquisition is placed by a sociocultural approach to language learning in a context of social practices (Lantolf, 2002).

\subsection{Language acquisition vs. Learning}

The acquisition and learning of a foreign language are two important concepts in the context of those who learn it and, above all, those who teach it. So, it is important that we focus on what differentiates them and for that we start by mentioning the two independent systems of second language performance, according to Krashen (1981): the acquired system and the learned system. According to the author, acquisition requires meaningful interaction in the target language 
- natural communication - in which speakers should not be so concerned with the form of the expressions they use, but with the messages they intend to convey, thus requiring significant interaction in the target language.

According to the aforementioned author, language acquisition is a subconscious and intuitive process, similar to the way children learn their native language, not requiring the extensive use of conscious grammar rules and not requiring boring exercises. As already mentioned, and as the author refers, the acquisition requires significant interaction in the target language - natural communication, where the focus should be on the message that the sender intends to transmit and not on the way his expressions will take. Considering this and still according to the same author, the best methods are, therefore, those that intend to provide "comprehensible input in low anxiety situations, containing messages that students really want to hear" (p. 7).

That is why methods that do not force early production in the second language are important here as they do not force early production in the second language, but allow students to produce when they are 'ready', recognizing that the improvement comes from providing understandable communication and contribution, and not from forcing and correcting production. A classic example of language acquisition is what happens in an exchange program. Those who attain near native fluency, while knowing little about the language in the majority of cases, intuitively are able to recognize and know how to use all the structures (Krashen, 1981).

The learned system or learning, in which a learner attends to form and is aware of his/her own learning process, is the product of formal instruction and it comprises a conscious process which results in conscious knowledge about the language, for example knowledge of grammar rules. In this approach the form is more important than communication. Teaching is focused on the language in its written form and the objective is for the student to understand the structure and rules of the language through the application of intellect and logical deductive interpretation. Predetermined syllabus rule teaching and learning in a formal instructional plan. We may say that one studies the theory in the absence of the practical. One values the correct and represses the incorrect. There is little space for spontaneity. It is a progressive and cumulative process, in which the teacher is an authority figure and the participation of the student is mainly passive.

The plain understanding of the distinctions between acquisition and learning makes it possible to examine their interrelationships as well as the implications for the teaching of languages: first, languages should be considered broadly as complex, subjective, unequal phenomena, full of ambiguity, in constant arbitrary and unmanageable development. Consequently, the grammatical structure of a language can be too complex and abstract to be classified and defined by rules. 
Even when some partial knowledge of the functioning of the language is achieved, this knowledge is not simply transformed into communication skills. Actually, we may observe a dependency predominantly opposite: to understand the functioning of a language as a system and to understand its irregularities is a function of familiarity with it. Grammar rules and exceptions make also sense if students have already enlarged concrete spontaneous control of the language in its oral form, i.e. when students have learnt it. Krashen acknowledged that the awareness acquired through formal study (language learning) can serve to monitor speaking. As a result, it is required to explore the degrees of irregularity and difficulty of the target language because the smaller the regularity, the fewer the rules and more limited the monitoring (Krashen, 1981).

In Krashen's opinion, language acquisition is more efficient than language learning and teaching should be personalized and based on the personal skills. Creating real communication focusing on students' interest must be a teachers' duty (Krashen, 1981).

\section{Communicative Language Teaching}

The need to learn a language and get in touch with speakers of another language is very old and is associated with social, economic, diplomatic, commercial or military reasons. It is believed that the first learnings of a foreign language happened through direct contact with the foreigner. However, in parallel with these language acquisitions in the natural environment, some people have systematized the teaching of some foreign languages, worrying about their study and learning.

As Richards and Rodgers (2001) pointed out, Europe needed to create a method where the emphasis was on communicative proficiency. Thus, in the seventies, Communicative Language Teaching (CLT), the Teaching of Communicative Language, emerged. CLT, as advocated by Richard and Rodgers, is generally regarded as an approach to teaching a foreign language (Richards \& Rodgers, 2001).

As such, the CLT reflects a particular research model or paradigm, or a theory (Celce-Murcia, 1991). This approach is based on the theory that the main function of language is communication and, therefore, its main objective is for students to develop their communicative competence (Hymes, 1972).

Resulting from the socio-cognitive perspective of sociolinguistic theory, with an emphasis on meaning and communication, and with the goal of achieving students' communicative competence, the Communicative Approach evolves as an important method in the teaching of foreign languages and gradually replaced previous methods such as the grammar and translation method and the audiolingual method (Warschauer \& Kern, 2000). 
Given the concept of communicative competence introduced by Hymes in the mid-1960s, many researchers helped to develop theories and practices of the communicative approach as in Brown (1987), Canale, (1983), Littlewood (1981), Nunan (1989) Richards \& Rodgers (2001) and Widdowson (1990). The concept coined by Hymes (1966) contrasted with Chomsky's linguistic competence. Chomsky (1965) believed that underlying concrete language performance, there is a system of abstract rules or knowledge and that underlying knowledge of the grammar of the language by the native speaker is its linguistic competence. In contrast, Hymes considered that, in addition to linguistic competence, the native speaker has another system of rules. In his view, language was seen as a social and cognitive phenomenon, i.e., syntax and forms of language were understood not as autonomous (structures without context), but as meaningful resources used in conventional and particular forms and developed through social interaction and assimilation of the speech of others (Warschauer \& Kern, 2000). Therefore, languages speakers must have more grammatical competence in order to be able to communicate effectively. In addition, in order to achieve the objective of communicating effectively, it is also necessary for them to know how the language is used by members of a given community (Hymes, 1972).

Based on this theory, Canale and Swain (1980) extended communicative competence into four dimensions. For these authors, communicative competence was understood as the underlying systems of knowledge and the necessary skill for communication. On the one hand, knowledge refers to what is known (consciously or unconsciously) about language and other communicative language aspects and on the other hand skill refers to how well this knowledge can be achieved in real communication.

From this perspective, it is concluded that what teachers need to teach in a language goes far beyond linguistic competence. Besides, teachers must also teach socio-linguistic competence, i.e, which utterances are produced and understood appropriately in different socio-linguistic contexts; discourse competence, i.e, mastery of how to combine grammatical forms and meanings to achieve a unified spoken or written text in different categories, and strategic competence, i.e, mastery of verbal and non-verbal communication strategies that may be called into action for compensating or improving communication (Canale \& Swain, 1980).

Bearing in mind the importance of what was mentioned and reflected earlier, foreign languages teachers at ESTGL outlined the methodology which is used in that Higher Education Institution and which is explained in the following paragraph:

Different types of exercises are used to promote the learning of different skills, but generally the methodology emphasizes the communicative approach (according to the teaching methodologies adopted by the course). The application of 
its basic principles allows students to develop the language and develop skills that will be necessary in their professional life. In addition, it emphasizes understanding and negotiating meanings and students learn to communicate through interaction, using appropriate morphosyntactic structures during the interaction. This approach also favours the instructional value of communication and develops cooperation and solidarity between students, assumptions that they will find during their professio nal life. It is, therefore, a student-centred approach. The contents taught and the methodology used are closely related to what the student learns and how he learns. Learning takes place in a real situational context in order to make common situations significant.

\section{Role playing as a vital activity to achieve both acquisition and learning}

It seems that there is little agreement on the terms used in the role playing and simulation literature:

Just a few of the terms which are used, often interchangeably, are "simulation," "game," "role-play," "simulation-game," "role-play simulation," and "roleplaying game" (Crookall and Oxford, 1990, as cited in Tompkins, 1998, para. 1)

As Tompkins (1998) states, there does seem to be some agreement, however, that simulation is a broader concept than role playing. While simulation is viewed by Ladousse (2004) as complex, lengthy, and relatively inflexible, role playing is viewed as quite simple, brief, and flexible. Simulations simulate real life situations, often involving a familiar or realistic situation in which a participant's role may not be as prominent or distinctive as it would be in a role-play. On the other hand, in role playing the participant is representing and experiencing some character type known in everyday life (Scarcella \& Oxford, 1992). Simulations always include an element of role play (Ladousse, 2004) and the difference is generally one of degree rather than kind.

There are many benefits of using role-play, such as Furness (1976) stated when he referred that we could enjoy and profit from a role-play experience. Besides having provided seventeen advantages of role-play, what we want to highlight here is that, in this author's opinion, communications skills, creativity, social awareness increasing, independent thinking, verbalization of opinions, development of values and appreciation of the art of drama are some of the advantages role-play can bring to those who use and take advantage of this technique.

The benefits of using role-play are recognized by the specialized literature and of which we highlight the contributions of Stern (1983) when he mentioned that "role playing helps the individual to become more flexible" and "to develop a 
sense of mastery in many situations". The same author also stated that "through role-play, L2 learners can experience many kinds of situations in which they will use the language; and as they develop a sense of mastery in them, they should be able to apply the language more easily to new situations"(p. 213).

In the wake of the recognition of the advantages in the use of role-play, Ladousse (2004) added that it is "one of a whole gamut of communicative techniques which develops fluency in language students, which promotes interaction in the classroom, and which increases motivation"(p.7). In addition to recognizing the advantages of fluency, promoting interaction and increasing motivation, according to the author, it allows responsibility for learning to be shared between teacher and students, as well as between colleagues. In his opinion, role-play is perhaps the "most flexible technique in the range of communicative techniques, and with suitable and effective role-play exercises, teachers can meet an infinite variety of needs" (Ladousse, 2004, p. 7).

As we can conclude by now, literate guides us to recognize that role-play technique has become a precious asset in the classroom for it allows students to engage in a learning process with a high level of motivation. It challenges their creativity and thinking in order to fulfil their roles as well as it helps developing their social skills. There is a kind of vitality that attends this type of imaginative activity and so it can be used to help students to become more interested and involved as they integrate the knowledge in action by addressing problems, exploring alternatives and looking for creative solutions, intensifying and accelerating learning. It is the best way to develop the skills of initiative, communication, problem-solving, self-awareness, and working cooperatively in teams, and prepare them to real life situations.

\section{Procedures when using role play at ESTGL}

In education, one of the most important aspects for an effective understanding of the methods and techniques used in a classroom requires communication that must be equally unambiguous. For this reason, it is important that the teacher explains exactly what language skills he/she wants to be achieved, as well as clarifies the reason why he/she chose to use that technique to achieve the objectives set.

Before using this technique, the teacher must ensure a learning environment in which the student feels safe. Literature points out, as in Jones (1982), that this technique should never be used at the beginning of classes, so that students do not feel pressured and it is also necessary for students to understand that they must face the challenge of playing a role, assuming the role assigned to them, accepting that role and not thinking that they are playing the role of a normal 
student in the classroom. This situation can be highly productive in the sense that the students get to play a different part. While using imagination as their starting point, they get to play someone else's part and be someone different. This situation will lead the student to an environment where the stimulus to create a role and to represent it will make the student aware of the commitment this task forces for its execution, regardless of the personality and personal characteristics that inhibit him/her from communicating with the other - assuming that it is the best way to abstract someone from his/her personality and focus on linguistic performance.

Once the contents to be taught are selected, the teacher should use the best materials to teach them. From the selected contents, the teacher decides which of them should be assessed by a students' final role-play, mainly those where the student is able to put his/her speaking skills at the service of effective communication in situations that although imaginary can be easily identified as real.

From this moment on, all the language used must be taught and explored so that students can choose the linguistic repertoire that best suits their level and pleases them the most. Role-play preparing activities are very time consuming, since the students' individual choice in relation to forms of communication that are most appropriate for them must always be respected. At the same time, the students are given time to simulate the language taught with the classmates in hypothetical situations created and students are invited to change roles so that they experience all possible language in the situation which is being explored.

As part of the student's individual assessment, all students have a role-play activity at the end of the year as part of their oral evaluation and their performance is assessed using carefully selected criteria so that all the work the student has done is valued at the assessment time. A student who is committed to the task from the beginning will easier understand that to communicate is the goal to be achieved. Although sentence accuracy and the use of language taught are objective of evaluation, the focus is on the ability to solve problems, on the identification of flaws throughout the path, on the creativity that will lead the student to select the more appropriate language and, above all, the way in which the student intelligently perceives that a complex communicational situation can be easily overcome if the other with whom he/she is interacting helps him/her in the communication process.

Another important aspect that should be considered is the process of choosing the pairs or groups that will perform the role-play. It is important that students relate to others so that the social skills are effective. Teachers must also be aware of the students' level so that students will not be discouraged, and their knowledge gap does not turn role playing into an intimidating and difficult activity. The main goal of role playing in class is not the language itself, rather 
the goals defined be the teacher, whether it is a matter of stimulating students' imagination or their speaking.

ESTGL foreign languages teachers have decided that the best solution for their role-plays should be pair work. Role playing activities can involve at least two students and, therefore, there is a chance for students to work together, which, for this reason, increases the time spent in the practice of the foreign language. Another advantage of working in pairs that the literature points out, as in Harmer (2001), is the fact that it allows students to work and interact autonomously, which promotes students' autonomy as well as cooperation, since everyone work and interact in the classroom. As far as the teacher is concerned, the fact that students are committed to work with their peers, this situation allows them to work with groups of students while others continue to work on the task.

Another important aspect that should be considered is the process of choosing the pairs or groups that will perform the task. As mentioned before, it is important that students relate to others so that the social skills are helpful and, of course, teachers must also be aware of the students' level so that students won't be discouraged, and their knowledge gap doesn't turn role playing into an frightening and problematic activity. At this stage, it is important that the teacher shares with the students that the main goal of using role playing in class is not the language itself, rather the goals defined. If the level or the role-play itself turns out to be difficult, the teacher should meet the students' needs and help them overcome their lack of experience or self-reliance and act as a participant to help the activity go along.

Having explored the definition of role-play, the organization that such activity requires, its advantages and the notion of pair work, another very important issue that must be clarified is the teachers' role in a role-play activity. Being a facilitator is one of the teacher's function. In order to play roles successfully, the students need to use the language required for the task and it is the teacher's responsibility to make sure the students learn the new language and while the learners perform role-play they may discover that they don't know some words or phrases and at this stage it is important that the teacher offers help whenever requested. Nevertheless, if rehearsal time is long enough, students have time to solve the problem alone and teachers' assistance might not be required. The second role that teachers play is the one of spectator, i.e., his or her task is to watch the role-play and then give remarks and advice at the end of the performances (Harmer, 2001). Finally, teachers' third role is being a participant. Although they should not participate too much, it is sometimes appropriate to get involved and take part in the role-play. His or her task is to prompt the exercise, introduce new information to help the role-play along and ensure continuing student engagement in the speaking (Harmer, 2001). 
After the activity, teachers give students the feedback of their performances. This is a crucial thing to do, either to discuss if the goal of the activity was achieved or to show students where the communication was effective or less effective.

\section{Conclusions}

Role-play can be an extraordinarily successful technique in a classroom, to be used and explored carefully. As its prime goal is to boost students' interaction in the classroom, educators should not forget about integrating such a speaking activity to reflect learners' theoretical knowledge of a language in practice. The teachers should give clear instructions, should encourage students during the process, should realize that her/his role should be reduced to the minimum possible during the process and should always support the students' needs when requested and whenever they cannot solve the problem by themselves. It is crucial to focus on the effective communication once it is more important than linguistic accuracy.

Although this work aimed to emphasize the use of such a particular technique as role-play, highlight its positive aspects and justifying its use in a specific context, we should not generalize and assume that it can always be used in all communicative contexts with all participants. Disadvantages, including organization and time constraints, and other aspects such as the teacher's role, the students' attitudes towards role-play, and the value of the mistakes (Livingstone,1983) should be taken as points for consideration before using this technique in a classroom. In Addition, setting up the background, contexts, and learning goals for the role play activities are also particularly important circumstances to consider before deciding using this activity. Lastly, some teachers might consider difficult to assess students' proficiency on their role play performance and must be aware of the challenge of evaluating students in that communicational context.

One of the primary concerns for those who teach foreign languages is to help students understand the importance of communication in real contexts. For this specific context, the role-play approach is one of the most powerful techniques a language teacher can explore as it enhances students' learning and prepares them to deal with all kind of speakers. Good students can help not so good students to communicate using the vocabulary they know, rephrasing complex sentences and achieve the same goal: communication.

One of the great challenges of a professor who teaches foreign languages at a higher education institution is to get all students to be motivated to communicate. Additionally, the selected topics always focus on specific purposes, adapted to the courses. As a matter of a fact, foreign language teachers must be in constant dialogue with those responsible for the curricular units in the main field of 
the courses so that they can outline the necessary skills that should be explored. For the preparation of this work, we counted on the collaboration of a colleague who works with contents from the main area of the degree in Secretarial Studies and Administrative Assistance, who helped us to select contents that later were assessed through role-play.

After years using such activities in the classroom, we have no doubts that through this activity students overcome their fear of speaking because so far, they had quite much time devoted only to speaking in the target language. Besides, having the change to work with partners boosts students' confidence and personal interaction skills.

In what comes to the teaching and learning of a language, this interactive method opposed to the usual teacher centred has proved to be richer, more effective and non-threatening to students, who evidently become more responsible, independent and dynamic as well as talkative. Role playing is surely an asset to both students and teachers when learning/teaching a foreign language. When this activity is thought of as an activity that improves students' language and personal skills and is truly planned, it becomes a rewarding experience for both students and the teacher.

\section{References}

Brown, H. D. (1987). Principles of language learning and teaching. Englewood Cliffs, NJ: Prentice-Hall.

Canale, M. (1983). From Communicative Competence to Communicative Language Pedagogy. In J. C. Richard, \& R. W. Schmidt (Eds.), Language and Communication (pp. 2-14). London: Longman.

Canale, M., \& Swain, M. (1980). Theoretical bases of communicative approaches to second language teaching and testing. Applied linguistics, 1(1), 2-43.

Celce-Murcia, M. (1991). Teaching English as a Second or Foreign Language. Boston, Mass.: Newbury House

Chesler, M. A., \& Fox, R. S. (1966). Roleplaying methods in the classroom. Chicago: Science Research Associates.

Chomsky, N. (1965). Aspects of the Theory of Syntax. Cambridge: M.I.T. Press
Crookall, D., \& Oxford, R. L. (1990). Linking language learning and simulation/gaming. In D. Crookall \& R. L. Oxford (Eds.), Simulation, gaming, and language learning (pp. 3-24). New York: Newbury House.

Ellis, R. (1997). SLA research and language teaching. Oxford: Oxford University Press.

Furness, P. (1976). Role-play in the Elementary School: A Handbook for Teachers. New York: Hart Publishing Company, Inc.

Guedes, A. (2009). Role Playing English. In EDULEARN09 Proceedings (pp. 564-570). Barcelona. ISBN: 978-84-612-9802-0

Hadley, A.O. (1993). Research in language learning: Principles, processes and prospects. Lincolnwood, IL: National Textbook Company.

Harmer, J. (2001). The practice of English language teaching. Harlow: Longman. 
Harrington, M. (2002). The Oxford handbook of applied linguistics. New York: Oxford University Press.

Hymes, D. H. (1966). Two types of linguistic relativity. In Bright, W. (ed.). Sociolinguistics. (pp. 114-158). The Hague: Mouton.

Hymes, D. H. (1972). On Communicative Competence. In J. B. Pride, \& J. Holmes (Eds.), Sociolinguistics: Selected Readings (pp. 269293). Harmondsworth: Penguin.

Jones, K. (1982). Simulations in language teaching. Cambridge: Cambridge U. Press.

Juffs, A. (2002). The Oxford handbook of applied linguistics. New York: Oxford University Press.

Kaplan, R. B. (Ed.). (2002). The Oxford Handbook of Applied Linguistics. Oxford: Oxford University Press.

Krashen, S. D. (1981). Second language acquisition and second language learning. Oxford: Pergamon Press.

Krashen, S. (1982). Principles and practice in second language acquisition. New York: Prentice-Hall.

Ladousse, G. P. (2004). Role Play. Oxford: Oxford University Press.

Lantolf, J. P. (2002). Sociocultural theory and second language acquisition. New York: Oxford University Press.

Larsen-Freeman, D. (2000). Techniques and principles in language teaching. New York: Oxford University Press.

Littlewood, W. (1981). Communicative language teaching. Cambridge: Cambridge University Press.

Livingstone, C. (1983). Role play in language learning. Harlow, Essex : Longman

Mitchell, R., \& Myles, F. (1998). Second language learning theories. London: Edward Arnold.

Nunan, D. (1989). Designing tasks for the communicative classroom. New York: Cambridge University Press.
Richards, J. C., \& Rodgers, T. (2001). Approaches and methods in language teaching. Cambridge: Cambridge University Press.

Scarcella, R., \& Oxford, R. L. (1992). The tapestry of language learning. Boston: Heinle and Heinle.

Schmidt, R. W. (1990). The role of consciousness in second language learning. Applied Linguistics, Vol. 11, Issue 2, 129-158. https://doi.org/1o.1093/applin/11.2.129

Siddiqui, M. (2008). Models of teaching. New Delhi: APH Publishing Corporation

Stern, H. H. (1983). Fundamental Concepts of Language Teaching. Oxford, England: Oxford University Press.

Tompkins, P. (1998). Role Playing/Simulation. The Internet TESL Journal, Vol. IV, No. 8. Retrieved from http://iteslj.org/Techniques/ Tompkins-RolePlaying.html

Swaffar, J., \& Bacon, S. (1993). Research in language learning: Principles, processes, and prospects. Lincolnwood, IL: National Textbook Company.

Warschauer, M. (2000). On-line learning in second language classrooms: An ethnographic study. In M. Warschauer, \& R. Kern (Eds.), Network-Based Language Teaching: Concepts and Practice (pp. 41-58). New York: Cambridge University Press. doi:10.1017/ CBO9781139524735.005

Warschauer, M., \& Kern, R. (2000). Networkbased language teaching: Concepts and Practice. New York: Cambridge University Press. doi:10.1017/CBO9781139524735.005 White, L., Bruhn-Garavito, J., Kawasaki, T., Pater, J, \& Prevost, P. (1997). Problems of ambiguity and preference in the investigation of reflexive binding. Language Learning, vol, 47, issue 1, 145-172. https://doi. org/10.1111/0023-8333.41997004

Widdowson, H. G. (1990). Aspects of language teaching. Hong Kong: Oxford University 